\title{
The effect of modeling approach in teaching catechesis vis-a-vis formation of value and prayer life of the Soup Kitchen Children in the Philippines
}

Credo, Maria Cristina

De La Salle University Manila, Philippines (maria_cristina_credo@dlsu.edu.ph)

Del Castillo, Fides $\$

De La Salle University Manila, Philippines (fides.delcastillo@dlsu.edu.ph)

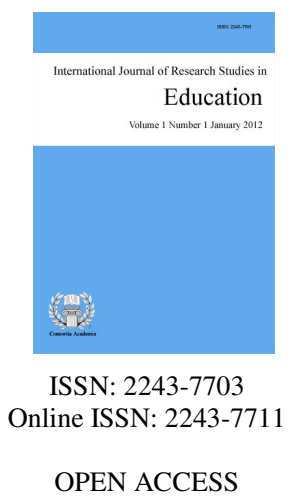

Received: 28 March 2019

Revised: 16 April 2019

Available Online: 1 July 2019

DOI: $10.5861 /$ ijrse. 2019.4907

Accepted: 29 May 2019

\section{Abstract}

Poverty is one of the main problems of the country. Many Filipinos live at the poverty level even though the government is always saying that the economy of the country is improving. The real score is that there are still a lot of Filipinos who are homeless, who are poor and who are hungry. Poverty has been the reason of some why they acquire vices and later commit crime. To at least alleviate the hunger of some and teaches virtues to avoid future problem in the country, contemplative religious congregation of nuns in a province in the Philippines opened a weekly soup kitchen. This soup kitchen program entails providing food for the children and at the same time giving catechesis for the children who attend on a regular basis. They also extend help to the children's families at least once a year. This study was conducted to find out if the children attending the soup kitchen increase in their practice of values especially honesty and respect and prayer through the example through the catechism input of the sisters. The prayer life in this research pertain to the basic prayers taught to the children if the children can pray it alone even outside the perimeter of the soup kitchen area. It is found out that the children attending the soup kitchen and catechesis have improved their practice of values though the result is weak with regards to the modelling showed by the sisters. However, the regularity of the attendance of the children and the catechism input had a strong relationship with the modelling showed by the sisters.

Keywords: modeling approach; catechesis; formation; soup kitchen; youth; spirituality 


\section{The effect of modeling approach in teaching catechesis vis-a-vis formation of value and prayer life of the Soup Kitchen Children in the Philippines}

\section{Introduction}

Last 2016, Pope Francis inaugurated the annual celebration of the World Day of the Poor, emphasizing that "the suffering and broken bodies of the poor are where we encounter the body of Christ - and that to know Christ we must know the poor" (Brockhaus, 2017). The Holy Father encouraged the faithful, saying that if every Christian wishes to encounter Christ, they have to touch His body in the suffering bodies of the poor as a response to the sacramental communion bestowed in the Holy Eucharist. He further explained that "The Body of Christ, broken in the sacred Liturgy, can be seen through charity and sharing, and in the faces and persons of the most vulnerable of our brothers and sisters. We may think of the poor simply as the beneficiaries of our occasional volunteer work, or of impromptu acts of generosity that appease our conscience. And these acts may be good for putting others needs more clearly before us, but what they should ultimately do is to lead to a true encounter with the poor and a sharing that becomes a way of life. This way of life gives rise to joy and peace of soul because we touch with our own hands the flesh of Christ." The Holy Father is calling upon all the faithful of the Church to recognize that helping the poor or those in needs is not limited to an occasional giving of reliefs or volunteer work, but more importantly it must become a daily encounter with the poor. St. Teresa of Calcutta, who has left us in this twenty-first century an outstanding witness to the call of compassion for the poor, had likewise stressed that the greater poverty of our generation is that of being hungry for love, for care and for mercy. Thus, within the Philippines, as a third-world country in which there is widespread poverty, Christians face the urgent challenge and call of the Church to realize the means of helping the poor in a way that is at the same time an encounter with Christ, becoming both a physical and spiritual sharing of Christian charity (Henkel, n.d.).

Recently, President Rodrigo Duterte signed into law the establishment of a national feeding program for undernourished children in public day care centers, kindergarten, and elementary school. It is called the Republic Act No. 11037 or the Masustansyang Pagkain para sa Batang Pilipino Act. It orders national government agencies to implement a program with three components. Supplemental Feeding Program for Day Care Children - Undernourished children ages 3 to 5 in day care centers are to be given at least one fortified meal (meal with improved nutritional quality based on government standards) for a period of at least 120 days in a year. This will be implemented by the Department of Social Welfare and Development and local government units (LGUs) (Ranada, 2018).

\subsection{Background of the Study}

Soup Kitchens have been established all over the world especially in areas where there are a lot of poor people. It started by providing soup to those in need, but it later developed into providing a full meal. In the present times, there are likewise groups who do not only give food but also clothing and other things that are available that might be needed by the recipients. This is an act of charity to others as the Lord calls everyone to extend help to those in need and open their hands to the poor.

The contemplative religious organization in a province in the Philippines opened a Soup Kitchen program six years ago, which is presently still operating, to become one of the means for them to respond to God's call to unconditional love for one's neighbor, love for the poor, and service to the universal Church. In the spirit of poverty, the nuns recognized that they could share the blessings of divine providence which they received through the instrumentality of generous benefactors with their poor neighbors, particularly the families in their neighborhood (Moya, 2014). The Soup Kitchen welcomed their neighbors, especially the children, to join in praying the Rosary in Eucharistic adoration, attend a short and basic Catechism lesson, and then enjoy a 
home-cooked meal. Through their encounter with the children and families, the nuns more so recognized not only the call to help their neighbors physically, but also the pressing spiritual hunger of today's young people and families for the presence and knowledge of God. This became the inspiration for firmly establishing the Soup Kitchen to not only be a mere feeding program for the body, but most especially a feeding program for the soul through means of catechism and leading them to the Eucharist. Thus, the Soup Kitchen Program of the congregation is interconnected with their Perpetual Eucharistic Reparative Adoration Apostolate, which is an apostolic endeavor inviting the faithful to discover and rediscover a deep love for the Holy Eucharist in the spirit of reparation. Along with the feeding program is the teaching of catechesis and prayer to the children and to form or develop good social and religious values. It is this aspect that the researcher wants to find out if the teaching of Catechesis and prayer helps in the formation of value of the children using the modelling approach of Albert Bandura.

\subsection{Conceptual Framework}

According to John Dewey, knowledge is an outcome of experience. There are many things in this world that is learned even without going to school. The first education is by apprenticeship; observing and experiencing. This is where most knowledge comes in. There are many things people will come to know if they have a lot of experience whether it be a successful experience or a failure experience. Both of these will have an impact on the person and certain knowledge will be inculcated to him or her (TheFamousPeople, n.d.).

Banning-Arndt (n.d.) noted that experiential education uses direct experiences as a means to explore, make sense of and come to understand larger, more complex topics by working in the outside world. It encourages learners to interact with their environment and to become involved by exploring concepts and content through hands-on experiences. Learning in this way engages an individual on every level; it brings together the intellectual curiosity with the ability to creatively problem-solve, experiment, persist and collaborate. Learning becomes more holistic, more meaningful and more personal this way. This way of learning, when complimented with what is learned in a classroom, is what can bring a subject to life.

David Kolb, a psychologist is also known for his theory of experiential learning and likewise supports the idea of John Dewey that children learn by experience. Kolb first outlined his theory of learning styles in 1984, which are now one of the best-known and widely used learning style theories. Jean Piaget in his educational philosophy also supports this learning through experience. Albert Bandura takes a step further however and believes that there are things that need not to be experienced in order to learn, and can be learned simply through observation. He also explains that through observation people learn first by catching the attention or the audience have the attention, then it follows by retention and lastly by assimilation. It is in this point that the researcher wants to find out if the children attending the soup kitchen learn (Olson \& Hergenhahn, 2009).

Figure 1, shows the relationship of teaching catechism using the modeling to the formation of values and prayer life of the soup kitchen children and how the profile and the socio economic of the respondents also affect their responses

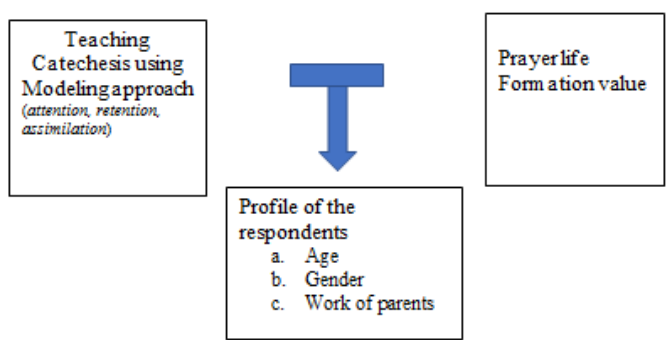

Figure 1. Framework of the study

\section{Review of related literature}

\subsection{The Soup Kitchen}

The philosopher Simone Weil wrote that feeding the hungry when one has resources to do so is the most obvious obligation of all. There are many groups in the Philippines who have established a soup kitchen in all 
different parts of the country. People in the vicinity of Quiapo, San Sebastian and Sta. Cruz; for example, know where to go to get their meal for breakfast, lunch, and dinner. In Tayuman, the SVD have their Kalinga where they do not only feed the hungry but also give them a bath. As Father Flaviano, SVD said that since the poor often have a disposition of inferiority, what they want to do is to establish their dignity as man. Different groups have different goals in such feeding programs.

A Soup Kitchen, as it is called by many is also known as a meal center, or food kitchen. It is a place where food is offered to the hungry for free, frequently located in an urban area or lower-income neighborhoods. It is typically underfunded and relies on volunteer staffing and goodwill donation of food and supplies (Eppich \& Fernandez, 2004). It is often staffed by volunteer organizations, such as church or community groups or even good hearted lay people. Soup kitchens sometimes obtain food from a food bank for free because they are considered a charity organization, which makes it easier for them to feed the many people who require their services. It started in the seventeenth century and was widely spread in America in the early years of the 19th century. Now it is widely known all throughout the world, and is part of the urban culture (Glasser 1998) to help those in need. In the United States, the Tabernacle Soup Kitchen considers such places as a culture of help because it is where one can see everyone helping one another. There are volunteers who do the feeding; there are those who do the cooking, and others who do the counselling or teaching.

Initially, soup kitchen referred to only the giving of food, but now a Soup Kitchen provides also a safe, clean, uplifting environment for those in need of food and fellowship. Some are also given clothes and medicine. It aims to serve the homeless, the working poor, the unemployed and their families. In short, it helps people who, through no fault of their own, find themselves in need.

For the Soup Kitchen program of the congregation, each community schedules a particular day of the week and time to hold the feeding program. Under ideal circumstances, a regular schedule is set on Sunday in coordination with an available priest, who can celebrate the Holy Mass and occasionally or regularly minister the Sacrament of Confession. Additional schedules during other days of the week and other times are at times set to appropriately cater to different audiences of the Soup Kitchen program such as for high school and college students or adults. However, the monastery is also open to the children or the poor who knocks at their door and asks for a meal any time of the day or week.

The regular weekly Soup Kitchen program, ideally scheduled on Sunday, is primarily catered to the neighborhood children between ages three to fifteen who are the beneficiaries of this program. These children who attend the soup kitchen belong to poor families within a low bracket of the economic status. Their parents most often are either farmers, laborers such as in construction, tricycle drivers, or even without a stable job. Some live in single-parent homes or come from broken families. The majority of these children are schooled in a public school within their barangay. As they participate, they have their meals and are sometimes given other items such as clothing, groceries, and school supplies to be brought home.

Servant of God Dorothy Day, known for the Catholic Worker Movement, said that food for the body is not enough; there must be food for the soul. Mostly religious groups and Christian groups who have the soup kitchen program also see to it that their patrons are not only fed by food but also by the word of God. In this way the patrons or the beneficiaries are instructed in things about faith and the love of God. First it is done through good works like feeding them, and making them feel that they are love by God, and then it precedes story telling or listening to them. It is in this experience that they little by little come to know God. Thus, aside from being fed, the children of the soup kitchen of the congregation have a rich experience wherein they learn things about God, how to socialize with people, and how to deal with problems in life with different situations presented to them as they learn values of honesty, industriousness, and respect not only to others but also to one self. The sisters start by teaching catechism through playing games or making art projects and crafts or storytelling. Sometimes they make use of videos. After a short catechism, the children are fed.

In the book of Coolman (2004), explaining the theology of William of Auxerre, Knowing God by 
Experience, he emphasizes the importance of the lectio divina, the study of the word of God, appreciation of all his creation, and most especially the active participation of the Eucharist because it is in the Eucharist that man and God meet its focal point. This reflects the value of also introducing the soup kitchen children to attend Sunday Mass either before or after the feeding program. It is in this way that the children are led to the encounter of God. Prior to the Mass, they are instructed on what is to happen during the celebration, they are taught the songs to be sung, and also practice the responses to be made so that the children are encouraged to participate well. Most of all, the children are taught about the importance of the Mass and its significance in their life through catechesis and examples of the saints. In the soup kitchen of the congregation, the children have first-hand experience of prayer, as they are taught to pray, led by example on how to pray and asked to pray on their own.

\subsection{The modeling approach and its components}

Young people are fond of having models or idols to which they are looking to imitate and to follow. If this is very much common to young people, much more is it among younger children who look to models not to idolize but to imitate. In the book of Philip Walshe (1968), The Furrow, he said that children look around themselves, and upon seeing some adults particularly father and mother, turning to God in prayer, or placing stress on prayer as most parents do in training their children to say their prayers or to behave well in church, they begin to recognize that this mode of action is important, and it is something they must attempt to do as well. As Charles Caleb Coton says, imitation is the sincerest form of flattery. The quote refers to paying someone an implied or unspoken compliment simply by following their example. By emulating the actions of others, one shows recognition of specific actions, view points, and values. Little children begin to learn about their environment through observation. This observation is sometimes called modeling, or indirect learning, as the new behaviors are learned through watching the behaviors and consequences of others.

The Modeling Approach (MA) is widely used by teachers in different disciplines. It can be used in science, math, music, art, philosophy, psychology, sociology and others. Some are actually using the MA without knowing it. The use of film and movies is one example of the MA by observing the example of the main character and being drawn to imitate his or her character. Another example is the use of the saints in a religious education class or world heroes in a social studies class. These are different ways of using the MA.

According to Eggen and Kauchak (2001), modeling effects a change in people that results from observing the actions of others. It is an instructional strategy in which the teacher demonstrates a new concept or approach to learning and students learn by observing. They also added that in modeling a certain behavior and learning in a class, a teacher also models her values (e.g. respect, kindness, honesty). Haston (2007) states that whenever a teacher demonstrates a concept for a student, that teacher is modeling. Biggs and Moore (1993) believe that teachers need to realize that there is no one way in which students go about learning; that some ways are more effective than others; and that, most importantly, there are things we as teachers can do to optimize the chances that students will go about learning in the most desirable ways. The teacher uses this approach to make the student visualize, observe and experience a certain character, behavior or values that the teacher wants to teach the students. This observation is called by Bandura as observation approach which is in a way the same as the MA.

\subsection{Bandura's way}

According to Albert Bandura, a psychologist, learning can also occur simply by observing the actions of others, though some would say that type of learning suggested that all learning was the result of associations formed by conditioning, reinforcement, and punishment. His theory added a social element, arguing that people can learn new information and behaviors by watching other people. Known as observational learning, this type of learning can be used to explain a wide variety of behaviors, including those that often cannot be accounted for by other learning theories. 
Bandura identified three basic models of observational learning: First, the use of a live model, which involves an actual individual demonstrating or acting out a behavior. Second, the use of verbal instructional model, which involves descriptions and explanations of a behavior. And lastly, the use of symbolic model, which involves real or fictional characters displaying behaviors in books, films, television programs, or online media.

Assimilation and accommodation by Jean Piaget are also similar concepts to that of the theory of imitability. To assimilate and accommodate needs a certain level of understanding. If mere assimilation, there would be no intellectual growth because one would just assimilate the cognitive structure. This is why there is a need of accommodation because it provides a process of mechanism for intellectual growth, the process in which the cognitive structure is modified.

Observation should lead to action. Students should try to put into action what they have observed and the experiences they were engaged in to give another learning. The knowledge or learning based from these experiences is sometimes permanent and lasting but there are also those that are only temporary. The learning experience is not necessarily all pleasant. Sometimes it is unpleasant and that is the learning the student derived from it. According to John Dewey "knowledge is the outcome of experience". It cannot be separated from the activity which is its origin. Hence, knowledge is constantly subjected to reconstruction, redirection and refinement. The reason for this is that experience needs to be subjected to constant change and improvement.

The experiential learning approach engages students in learning activities that give them opportunity to interact with other learners on a particular issue or topic. Then they reflect and analyze, after which they form the generalization from the discussion. A follow up activity enables them to affirm their understanding or insight. Activity-oriented experiences engage the students in the learning process. Learners learn more when they are involved in the activities. This theory is suggested by Dewey, Piaget, and Carl Rogers. Children learn more by trying to carry out activities either individually or in group.

The MA can be said to encompass both such observational and experiential approaches, shows modeling to be an effective instructional strategy among the young people. It allows students to observe the teacher's thought processes and experience them first hand. In religious education with the intention of molding the behavior and attitude of the students the teacher should set a good example (Tulpa, 1935). Using this type of instruction, teachers engage students in imitation of particular behaviors that encourage learning not only cognitively, but affectively and personally.

Research has shown that modeling can be used across disciplines and in all grade and ability level classrooms. According to social learning theorist Albert Bandura, learning would be exceedingly laborious, not to mention hazardous, if people had to rely solely on the effects of their own actions to inform them what to do. Fortunately, most human behavior is learned observationally through modeling: from observing others one forms an idea of how new behaviors are performed, and on later occasions this coded information serves as a guide for action. Bandura further discussed that observation may not be enough.

\section{Research methodology}

The researcher made use of the descriptive method. Since the researcher wants to find out the effect of the MA she will be needing data to find out her inquiries. According to Valdez (2010) this method is portrayal of data, process and problems and its characteristics about a population or phenomena. This method is designed for the investigator to gather information about present existing conditions. The principal aim of imploring this method is to describe the nature of a situation as it exist at the time of the study and to explore the causes of particular phenomena.

\subsection{Respondents of the study}

Since the research wants to find out the effect of the MA in the soup kitchen children, the respondents are 
Modeling approach in teaching catechesis vis-a-vis formation of value and prayer life of Soup Kitchen Children those who are participating in the soup kitchen program of the congregation, in this research it particularizes the audience in the community in the Philippines.

\subsection{Sampling techniques}

There is no sampling techniques use in getting the number of the respondents, though the researcher limits the age bracket of those who will answer the questionnaire. Only those who are from the age of nine (9) and above are allowed to answer the questionnaire for they are the one who have the better understanding of the questions

\section{Presentation, interpretation and analysis data}

\subsection{The profile of the respondents}

There are $33 \%$ male and $67 \%$ female respondents. Majority of the respondents are 11 years old which is $36 \%$ of the total respondents or 9 out of 24 . The second largest age group of the respondents is twelve years old which is $20 \%$ or 5 of the total number of the respondents, the third highest number is the group for those who are ten years old which is $16 \%$ or 4 children, and the fourth is the group of those who are 9 years old which is $12 \%$ or 3 children. Those who belong to the age groups 13,14 and 15 have only $4 \%$ or only 1 child. $91 \%$ of the participants regularly attend the program. Attendance is a necessary factor to find out if those who are have regular attendance have a good faith formation and have acquired the virtues, especially that of honesty and respect and also have learned to pray and gained knowledge of some basic aspects of the Catholic Faith. The result of the survey shows that all the fathers of the respondents are working and consider their work as non-professional work or blue collar jobs. Such type of work includes being a carpenter, painter, driver, vendor, domestic worker, assistant worker. Among the mothers of the respondents, which is shown in graph B, 69.6\% of the mothers are not working while the other $30.4 \%$ works. Among those who are working mothers $21.7 \%$ work on a non-professional job while $8.7 \%$ of the working mothers are working a professional job, which includes being a midwife and a manager, though the respondents did not specify what kind of manager.

\subsection{Perception of the respondents}

The table 1 presents the perception of the respondents on the effectiveness of the catechism input on the soup kitchen program of the nuns. The table shows that all the questions with regard to the input of catechesis the children have a higher mean value meaning that the respondents consider the input as effective. Questions 6 and 10 with the mean of 4.96 and 5.00 relatively show the modelling of the sister as seen by the soup kitchen children. Another modelling is in the queston\#3 which is the modelling of the saint which has also have a mean of 5.00 which is also highly effective in the teaching of catechesis.

\section{Table 1}

Perception on the effectiveness of the catechism input on the soup kitchen program of the nuns

\begin{tabular}{|c|c|c|c|c|}
\hline & Items & Mean & $S D$ & Level of importance \\
\hline 1. & $\begin{array}{l}\text { ang magandang halimbawa na ipinamamalas ng mga sister ay } \\
\text { nakakatulong sa paghubog ng aking kagandahang asal }\end{array}$ & 4.92 & .408 & Highly Important \\
\hline 2. & nagdarasal ako kahit walang nakatingin sa akin & 4.88 & .338 & Highly Important \\
\hline 3. & $\begin{array}{l}\text { hindi ako sumsagot sa aking mga magulang gaya ng turo ni } \\
\text { sister }\end{array}$ & 4.46 & .932 & Highly Important \\
\hline 4. & humahanga ako sa kabutihang pinapakita ng mga sister & 5.00 & .000 & Highly Important \\
\hline 5. & ang mga madre na nagtuturo sa amin ay mapagpasensya & 5.00 & .000 & Highly Important \\
\hline 6. & $\begin{array}{l}\text { gusto kong maging matiyaga para maging matagumpay ako sa } \\
\text { buhay }\end{array}$ & 5.00 & .000 & Highly Important \\
\hline 7. & $\begin{array}{l}\text { nag-aaral ako ng mabuti bilang pagpapahalaga sa paghihirap } \\
\text { ngaking mga magulang }\end{array}$ & 5.00 & .000 & Highly Important \\
\hline
\end{tabular}


Table 1 ... continued

\begin{tabular}{llccc}
\hline \multicolumn{1}{c}{ Items } & Mean & $S D$ & Level of Importance \\
\hline 8. $\quad \begin{array}{l}\text { hindi ako nangongopya dahil sabi ni sister ay kasalanan daw } \\
\quad \begin{array}{l}\text { iyon } \\
\text { hindi ako nagsisinungaling at sinasabi ko kung ano ang }\end{array}\end{array}$ & 4.79 & .415 & Highly Important \\
& 4.67 & .565 & Highly Important \\
katotohanan & 4.75 & .608 & Highly Important \\
\hline 10. $\quad$ marunong akong gumalang sa mga nakakatanda sa akin & & & &
\end{tabular}

Note. Items are in the Filipino language.

The table 2 represents the perception of the respondents on the importance of the values learned in the soup kitchen especially that of honesty and respect. Looking at the table it shows that all the questions with regard to the formation of values have the high mean value which is highly important, the children consider that all the questions in the formation of values as highly important. The values of honesty \#8, \#9 with the mean of 4.79 and 4.67 respectively also have a highly effective and the questions on the value of respect \#3 and \#10 with 4.46 and 4.75 respectively also show highly effective. It can be interpreted that children who go regularly in the soup kitchen have grown in their value of honesty and respect and they consider it important.

\section{Table 2}

Perception on the importance of the values learned in the soup kitchen especially that of honesty and respect

\begin{tabular}{|c|c|c|c|c|}
\hline Items & & Mean & $S D$ & Level of effectiveness \\
\hline 1. & masayang mag-aral sa kumbento ng kaalaman tungkol sa diyos & 4.83 & .565 & Highly Effective \\
\hline 2. & nadagdagan ang aking kaalaman tungkol sa diyos. & 4.92 & .408 & Highly Effective \\
\hline 3. & maganda ang halimbawang pinapakita sa buhay ng mga santo & 5.00 & .000 & Highly Effective \\
\hline 4. & $\begin{array}{l}\text { naiinganyo ako sa mga ginagawa naming tuwing lingo gaya ng } \\
\text { pagguhit, pagkulay at paglalaro }\end{array}$ & 4.92 & .282 & Highly Effective \\
\hline 5. & natututo ako ng mga kaalaman tungkol kay mama mary & 5.00 & .000 & Highly Effective \\
\hline 6. & nakikita ko na matiyaga ang mga sister sa pagtuturo sa amin & 4.96 & .204 & Highly Effective \\
\hline 7. & $\begin{array}{l}\text { natututunan ko rin ang mga awit na pang simbahan at } \\
\text { nakaktulong ito sa aktibong paglahok sa santa misa }\end{array}$ & 4.96 & .204 & Highly Effective \\
\hline 8. & $\begin{array}{l}\text { mahalaga ang mga bagay na natutunan ko sa paghubog ng aking } \\
\text { kagandahang asal }\end{array}$ & 4.88 & .448 & Highly Effective \\
\hline 9. & natututo akong magdasal sa oras ng pangangailangan & 4.58 & .881 & Highly Effective \\
\hline 10. & maraming kaalaman akong natutunan kina sister & 5.00 & .000 & Highly Effective \\
\hline
\end{tabular}

Table 3 shows the correlation of the age of the respondents with the three areas of the soup kitchen program of the nuns. According to the data the age of the respondents when correlated to the formation of values it shows a significant relationship of moderate. It can be interpreted that as the person is growing older the values are formed. With regard to prayer and catechesis, it shows a weak relationship with the age of the person that the age is not related with regard to catechesis and prayer.

\section{Table 3}

Correlations of the respondents' age with the three goals of the soup kitchen program

\begin{tabular}{lccc}
\hline \multicolumn{1}{c}{ Age } & Correlation Coefficient & Sig. (2-tailed) & Degree of Correlation \\
\hline Formation of Values & .514 & .010 & Moderate \\
Prayer Gestures & .222 & .297 & Weak \\
Catechism Input & .063 & .768 & Very weak \\
\hline
\end{tabular}

Table 4 shows the correlation of the attendance of the respondents to the three areas of the soup kitchen of the nuns. As seen in the table the attendance of the respondents has a moderate degree of relationship when correlated to the catechesis input, while when correlated to the formation of values and prayer it shows a weak relationship. It can be interpreted according to the data that that children who regularly attend the soup kitchen has a relationship with the input of the catechism which means that they learn the teachings of the sisters weekly, while the weak relationship to values and prayer can be interpreted that their weekly attendance has a weak 
Modeling approach in teaching catechesis vis-a-vis formation of value and prayer life of Soup Kitchen Children relationship with their formation of values and prayer that means is it not that as related to their attendance.

\section{Table 4}

Correlations of the respondents' attendance with the three goals of the soup kitchen program

\begin{tabular}{lccc}
\hline \multicolumn{1}{c}{ Attendance } & Correlation Coefficient & Sig. (2-tailed) & Degree of Correlation \\
\hline Formation of Values & .349 & .095 & Weak \\
Prayer Gestures & .235 & .268 & Weak \\
Catechism Input & .448 & .028 & Moderate \\
\hline
\end{tabular}

Table 5 presents the correlation between modelling questions and the different variables. Using Spearman's rho correlation the data shows that the modelling questions has a strong relationship with the attendance of the respondents on the soup kitchen program. These modelling questions is extract from the questionnaire, the questions related to the modelling of the sisters is correlated with these and find out that only the attendance of the respondents are related. It can be interpreted that their attendance is related because it is their presence in the soup kitchen that makes them see the modelling of the examples shown by the sisters.

\section{Table 5}

Correlations between modelling questions and the different variables using Spearman's Rho

\begin{tabular}{lccc}
\hline \multicolumn{1}{c}{ Modelling questions } & Correlation Coefficient & Sig. (2-tailed) & Degree of Correlation \\
\hline Age & .230 & .281 & Weak \\
Grade Level & .257 & .225 & Weak \\
Father Occupation & - & - & \\
Mother Occupation & .252 & .246 & Weak \\
Attendance & .833 & .000 & Very Strong \\
\hline
\end{tabular}

Table 6 represents the correlation between modelling questions and the three areas of the soup kitchen of the sisters. The data shows that only the catechism input has a strong relationship with regard to the questions of the modelling of the sisters or the example shown by the respondent. It can be interpreted that since the respondents come on a regular basis the example shown by the sisters is of great help for the catechism input, which means that the children learn through the example shown by the sisters.

\section{Table 6}

Correlations between modelling questions and the three goals of the soup kitchen program

\begin{tabular}{lccc}
\hline \multicolumn{1}{c}{ Modelling questions } & Correlation Coefficient & Sig. (2-tailed) & Degree of Correlation \\
\hline Formation of Values & .374 & .072 & Weak \\
Prayer Gestures & .374 & .072 & Weak \\
Catechism Input & .615 & .001 & Strong \\
\hline
\end{tabular}

\section{Summary of findings, conclusions, and recommendations}

The following are the findings of the researcher on the study made. First, the gender does not show so much difference in the participation of the children, but rather what makes the difference is the culture. Second, the age of the children attending the soup kitchen mostly belongs to the age groups of 9, 10, 11, and 12. When the children started to enter their teen years; their attendance declines. Third, the socio economic status of the children does not show great difference with regard to the attendance of the children. The poorer children come for food, while those whose parents are working come for companionship and socialization as well. Fourth, the children find the modeling or the examples of the sisters as effective in teaching catechesis. Fifth, the children find the values of respect and honesty as important. Sixth, the children grow older, they also grow in values. And lastly, the modeling or example of the sisters helps in the frequenting of the children to attend the soup kitchen program and in learning the catechism.

\subsection{Conclusion}

The soup kitchen program of the Contemplative of the Two Hearts helps the neighboring families in a 
province in the Philippines. Aside from the meals and goods they give to the children and their families, they also conduct formation or catechesis especially for the children with the aim of forming their values and lead them to a prayerful life. In general, all the children attending the soup kitchen belong to families in the lower bracket of the society. There are some children with both parents working yet they still find the soup kitchen as a source of companionship since both parents are not at home. The children also find that honesty and respect which are two of the virtues formed as important. Though the result of the test shows a weak significant relationship between the modelling and the teaching of the catechesis to the formation of values of the children, the hypothesis is not accepted because there is a little relationship or weak relationship between the two. That means that the relationship is very little between the values of honesty and respect to the modelling of the sisters. The researcher somehow accepted that maybe if there is a thorough study and a very good questionnaire that is fit in the study the result will be better because somehow it is very obvious that the learning affect in the formation of the values of the person.

Note: Part of this paper was also presented in the 3rd Lumina Research Congress held in Kuala Lumpur, Malaysia on February 23 to 24, 2019.

\section{References}

Banning-Arndt, Q. (n.d.). Learning through experiences. Retrieved from https://www.gobroadreach.com/blog/experiential-education/

Biggs, J., \& Moore, P. (1993). The process of learning. Sydney: Prentice Hall.

Brockhaus, H. (2017). For first world day of the poor, Francis encourages personal encounter. Retrieve from https://www.catholicnewsagency.com/news/for-first-world-day-of-the-poor-francis-encourages-a-perso nal-encounter-12201

Coolman, B. T. (2004). Knowing God by experience: The spiritual senses in the theology of William of Auxerre. Washington, DC: The Catholic University of American Press.

Eggen, P., \& Kauchak, D. (2001). Educational psychology: Classroom connections (5th ed). New York: Macmillan.

Eppich, S., \& Fernandez, C. P. (2004). Study finds Chapel Hill, NC, soup kitchen serves nutritious meals. Journal of the American Dietetic Association, 104(8), 1284-1286. https://doi.org/10.1016/j.jada.2004.05.208

Glasser, I. (1988). More than bread, ethnography of a soup kitchen. Turcaloosa, Alabama: University of Alabama Press.

Haston, W. (2007). Teacher modelling as an effective teaching strategy. Music Educators Journal, 93(4), 26. https://doi.org/10.1177/002743210709300414

Henkel, L. (n.d.). St. Arnold Janssen Kalinga center: Making a difference. Retrieved from http://www.svdvocations.org/about-divine-word/ministries/kalinga-center

Moya, G. P. (2014). Manila's soup kitchens. Retrieved from https://www.rappler.com/move-ph/issues/hunger/53594-soup-kitchens-manila

Olson, M., \& Hergenhahn, B. R. (2009). An introduction to theories of learning (8th ed.). Upper Saddle River, NJ: Pearson Education.

Ranada, P. (2018). Duterte signs law on national feeding program. Retrieved from https://www.rappler.com/nation/206418-duterte-signs-national-feeding-program-law

TheFamousPeople. (n.d.). John Dewey. Retrieved from https://www.thefamouspeople.com/profiles/john-dewey-144.php

Tulpa, L. (1935). Religious education as character training: A study in philosophy and psychology of religious education and character training. New York: JJ Ives Company.

Walshe, P. (1968). Supplement: Catechetics. The Furrow, 19(10), 12-17. 